\title{
The Influence of M\&As on Firm Value: The Turkish Experience
}

M. Nihat Solakoğlu and Mehmet Orhan

\subsection{INTRODUCTION}

World economies were exposed to several merger and acquisition waves within the last century. Moreover, more recently, a shift of M\&A activities from regional to more global nature has been observed (Gugler et al. 2003). These waves, as discussed in the literature, can occur either because of some type of industry shocks or because of market timing Harford (2005) ${ }^{1}$. Up until the last decade, though, Turkish economy did not have a significant experience with mergers and acquisitions, either domestic or crosscountry. More global nature of M\&A activities and the emergence of the Istanbul Stock Exchange (ISE) played an important role in this change. In particular, it became less costly for Turkish firms to raise capital and consider strategies to acquire or merge with other firms. In addition, it can be argued that existence of the stock exchange has caused information and monitoring costs to fall with improved regulations and laws. As a result, it became easier for acquirer and target firms to evaluate costs and benefits of merging or acquisition strategies.

As discussed by previous studies, there are several reasons that explain why M\&A activity leads to an improvement on firm value. These reasons mainly fall under two groups that are linked to managerial motivations: reasons that reflect self-serving motivations or that not. When the motivations are not related to self-interest of managers, M\&A activity should lead to a positive impact on shareholder wealth and hence on firm value. 
The increase in shareholder wealth may be caused by cost reduction (due to expense reduction or lower adverse selection costs), efficiency improvements, risk reduction (due to diversification), or increased market power (if firms operate in the same sector) ${ }^{2}$. On the other hand, when the motivation is related to self-interest of managers ${ }^{3}$, one should not expect to observe an increase in firm value (e.g., Peristiani, 1997; Cheng et al., 2004) ${ }^{4}$. Previous research also indicates that source of financing, cash or stock, can be an important determinant of M\&A impact on firm value (e.g., Andrade et al., 2001).

One group of studies focus on the short-run impact of M\&As on target and acquiring firms by using an event-study analysis. An evaluation of stock returns relative to the expected levels around the announcement date is expected to reveal investor expectations about the value change as a result of merger or acquisition. In other words, these studies show how investors appraise the M\&A activity. In addition, most studies form a consensus that target firm returns show a positive abnormal return while acquiring firm returns do not change significantly (e.g., Cheng et al., 2004; DeLong, 2001; Scholtens and de Wit, 2004; Kıymaz, 2004; Amihud et al., 2002).

Traditional approach to test the long-run effects of M\&A includes the comparison of pre- and post-merger accounting data. Mainly, studies show that short-run improvements are not realized in the long-run (e.g., Cheng et al., 2004). Other measures of long-run performance are also used in the literature to evaluate the long-run impact of M\&A activity on firm value. Some alternatives are X-efficiency and scale efficiency. It can be argued that these are better measures for cost efficiency than financial ratios and they can be more effective to examine long-run effects of mergers (e.g., Peristiani, $1997)^{5}$. It is also possible to argue that innovative performance of the firm after the merger should be higher due to improved post-merger knowledge base (e.g., Cloodt, 2006) ${ }^{6}$.

There is also a large and growing literature on the effects of cross-border mergers and acquisitions on firm value ${ }^{7}$. Cross-border M\&As do not only cause a reallocation of resources within/across an industry and national borders, but also between nations and even regions. Research reveals that both geographic concentration and activity focus are important for crossborder M\&A to be value increasing (DeLong, 2001). In addition, differences in laws and regulations and investor protection are also important factors to determine the cross-border merger patterns and success rate (Rossi and Volpin, 2004; Buck and DeLong, 2004) ${ }^{8}$. Although there are some differences in findings, as in domestic M\&As, research indicates that wealth gains mostly accrue to target firms rather than acquiring firms for crossborder M\&As (e.g., Kıymaz, 2004; Gugler et al., 2003; Bessler and Murtagh, 2002; Kıymaz and Mukherjee, 2001).

As indicated earlier, the low volume of M\&A activity, both in numbers and in value, including a Turkish firm either as a target or a bidder has prevented researchers in the past evaluating the M\&A impacts on firm value. Within the last decade but in particular within the last couple of years, this 
situation has changed significantly. For instance, while there were only five completed mergers and acquisitions in 1997, we can find 164 announced cases in $2005^{9}$. Although the number of M\&A activity looked somewhat higher since 1998, a close examination of the transaction value of M\&A activity indicates that 2005 was different than earlier years ${ }^{10}$. While the total transaction value was US $\$ 613.7$ million in 2002, for 2005 the transaction value rose to US $\$ 30.4$ billion. Even in 2004, the announced value was much lower and it was around US $\$ 2.5$ billion. Clearly, the role and significance of M\&As for Turkish economy started to change dramatically around 2005 (Aydın, 2004; Ernst \& Young 2005 M\&A report).

The majority of M\&A activity over the last decade in Turkey can be considered domestic rather than cross-border. However, along with growing M\&A activity in 2005, we also observe growing importance of cross-border acquisitions and mergers. For example, share of cross-border activity was around twenty percent in 2003. In 2005, however, about thirty-nine percent of total activity was cross-border. Moreover, European firms lead the foreign firms, either as bidder or target, in the cross-border M\&A list (Ernst \& Young 2005 M\&A report).

This study investigates the impact of mergers and acquisitions on firm value for the Turkish target and acquiring firms. Given the recent nature of M\&A activity in Turkey, firm value is evaluated in the short-run through an event-study analysis. In other words, we consider a positive return over expected around the announcement date as an increase in firm value. Additionally, we examine the role of firm-specific and merger-specific factors on the sign of the M\&A impact on firm value. In other words, we try to identify the factors that significantly impact the probability of observing a positive abnormal return by utilizing logistic regression approach ${ }^{11}$. The remainder of the paper is organized as follows. Section II discusses data sources, and the methodology to analyze short-term impact of M\&A on firm value. Discussion of results is left to section III. Last section presents our main conclusions and suggestions for further research.

\subsection{DATA AND METHODOLOGY}

Our analysis is performed using merger and acquisition data obtained from Bloomberg through a local investment firm. Dataset covers most of the announced activity between late 2003 and middle of 2006. Although the Turkish economy experienced a total of 389 M\&As between 2003 and 2005, we could only identify 38 activities that includes at least one firm that is traded in the Istanbul Stock Exchange. For 2006, we identified an additional 14 firms, providing us a total of 52 acquirer and target information, with 30 being for the target ${ }^{12}$. Consistent with the observed trend in M\&A activity in Turkey, the majority of transactions were also between Turkish firms in this sample. In addition, about $42 \%$ of the transactions could be categorized as 
cross-border, with mostly foreign firms bidding for Turkish firms. Moreover, about $57 \%$ of the M\&A activity included firms operating in the same industry. Particularly for cross-border activity, $73 \%$ of the acquirer and target firms were operating in the same industry. Within this sample, M\&A activity seems to concentrate in financial and consumer goods sectors.

Daily data of securities traded at the Istanbul Stock Exchange (ISE) and market index ${ }^{13}$ are obtained from www.analiz.com for the acquirer and bidder firms in our sample. The following specification of the market model is used to determine the expected returns in our analysis:

$$
R_{i t}=\alpha_{i}+\beta_{i} R_{m t}+\varepsilon_{i t}
$$

where $R_{i t}$ is the daily return of security $i$, and $R_{m t}$ is the market return at time $t$. $\varepsilon_{i t}$ is the disturbance term satisfying the classical assumptions. We estimate the model above with 80 observations dating over $[-90,-11]$ days before the announcement. The event window includes 20 days around the announcement date. The abnormal returns are the OLS residuals over the subperiod defined as:

$$
A R_{i t}=R_{i t}-\left(\hat{\alpha}_{\mathrm{i}}+\hat{\beta}_{\mathrm{i}} R_{m t}\right)
$$

The abnormal returns for each day of the event window over the firms are calculated and reported in Table 6.1 and Table 6.2 to present some characteristics of these returns for different days of the event window for target and acquiring firms, respectively. Although the mean of abnormal returns are oscillating around zero throughout the event window, there is a slight decrease in the trend. The dispersion also has such a trend, which is somewhat smaller in magnitude, but the more striking characteristic of the dispersion indicated by the standard deviation is the peak it attains in the immediate neighborhood of the announcement day. The lowest minimum is at the exact date of the announcement with $-21.4 \%$, and the maximum is incidentally attained just before that day with the same percentage.

A crucial point of interest is whether the population mean of the abnormal returns is significantly different than zero or not. More formally; the null of $H_{0}: A A R=0$ is to be tested against the alternative of $H_{1}: A A R \neq 0$ at various significance levels for both acquiring and target firms. The corresponding test statistic is the ratio of the mean to the standard deviation of the sample mean, i.e. $t=\left(\bar{x}-\mu_{0}\right) /(s / \sqrt{n})$ where $\bar{x}$ is the sample mean, $s$ is the sample standard deviation and $n$ is the sample size. This test statistic follows the Student's t-distribution with $n-1$ degrees of freedom. Last columns of Tables 6.1 and 6.2 are the t-statistics where $\left({ }^{* *}\right),\left({ }^{* *}\right)$, and $\left(^{*}\right)$ denote significances at $1 \%, 5 \%$, and $10 \%$ levels, respectively. The abnormal returns prove to be significantly different than zero for the majority of the days belonging to the event window for the target firms. 
Table 6.1 Descriptive statistics belonging to target firms

\begin{tabular}{|c|c|c|c|c|c|c|c|c|c|}
\hline Day & Mean & Med. & St. Dev. & Kurt. & Skew. & Range & Min. & Max. & t-stat. \\
\hline-10 & 0.89 & -0.01 & 3.13 & 8.81 & 2.62 & 16.16 & -2.64 & 13.50 & $1.55\left(^{\star *}\right)$ \\
\hline-9 & 0.94 & -0.00 & 3.34 & 0.00 & 0.50 & 14.01 & -6.50 & 7.51 & $1.54\left({ }^{* *}\right)$ \\
\hline-8 & 1.16 & 0.22 & 2.63 & 2.07 & 1.30 & 12.36 & -3.59 & 8.76 & $\left.2.42^{(\star \star *}\right)$ \\
\hline-7 & -0.13 & -0.27 & 2.62 & 5.34 & 1.54 & 14.14 & -4.76 & 9.38 & -0.28 \\
\hline-6 & -0.07 & -0.15 & 3.14 & 9.31 & 2.02 & 19.46 & -6.81 & 12.70 & -0.11 \\
\hline-5 & 0.62 & 0.29 & 2.68 & 0.09 & -0.10 & 11.93 & -5.35 & 6.58 & $1.27\left(^{*}\right)$ \\
\hline-4 & 0.27 & 0.11 & 2.53 & 2.62 & 0.53 & 13.73 & -5.64 & 8.09 & 0.58 \\
\hline-3 & 0.88 & -0.34 & 4.02 & 1.86 & -0.49 & 19.01 & -11.5 & 7.49 & $1.20\left(^{*}\right)$ \\
\hline-2 & 1.05 & 1.04 & 3.56 & 3.77 & -0.68 & 20.13 & -10.6 & 9.54 & $1.62\left(^{* *}\right)$ \\
\hline-1 & 0.94 & 0.43 & 7.22 & 2.17 & 0.62 & 35.59 & -14.1 & 21.40 & $0.71\left(^{*}\right)$ \\
\hline 0 & -1.24 & 0.32 & 7.01 & 2.90 & -0.64 & 38.75 & -21.4 & 17.30 & $-0.97\left(^{*}\right)$ \\
\hline 1 & -0.15 & -0.88 & 5.02 & 4.47 & 1.58 & 26.24 & -8.61 & 17.60 & -0.16 \\
\hline 2 & 0.54 & -0.29 & 2.94 & 2.28 & 1.28 & 14.25 & -4.59 & 9.66 & $1.00\left(^{*}\right)$ \\
\hline 3 & -0.60 & -0.32 & 2.98 & 3.59 & -1.40 & 15.40 & -10.3 & 5.09 & $-1.11\left(^{*}\right)$ \\
\hline 4 & -0.46 & -0.39 & 2.32 & 0.37 & -0.52 & 10.22 & -6.04 & 4.18 & $-1.10\left(^{*}\right)$ \\
\hline 5 & 0.16 & -0.34 & 2.39 & 2.34 & 1.47 & 10.72 & -3.41 & 7.31 & 0.36 \\
\hline 6 & -0.31 & -0.68 & 3.00 & 7.64 & 1.91 & 16.75 & -5.36 & 11.40 & -0.56 \\
\hline 7 & -0.83 & -0.51 & 2.18 & 1.18 & -1.11 & 9.20 & -6.64 & 2.56 & $\left.-2.08{ }^{* * *}\right)$ \\
\hline 8 & 0.41 & -0.15 & 3.47 & 8.11 & 2.38 & 18.72 & -4.55 & 14.20 & 0.64 \\
\hline 9 & -0.04 & -0.07 & 2.63 & 0.48 & 0.06 & 11.58 & -5.95 & 5.63 & -0.09 \\
\hline 10 & -0.78 & -1.07 & 2.25 & 0.96 & -0.01 & 11.12 & -6.68 & 4.43 & $\left.-1.87^{* * *}\right)$ \\
\hline
\end{tabular}

Source: www.analiz.com

We observe less significance in average abnormal returns being other than zero for the acquiring firms as displayed in the last column of Table 6.2. Furthermore, days with significant average abnormal returns are smaller (11 out of 23) as well.

\subsection{DISCUSSION OF RESULTS}

Another point of interest is how the Cumulative Abnormal Returns (CAR) are changing over the event window . We define the CAR for any day $t$ (inside the event window from -10 to 10) as the sum of the average abnormal returns up to that day as $C A R(t)=\sum_{i=-10}^{t} A A R_{i}$. Figure 6.1 displays how the $\mathrm{CAR}$ changes throughout the event window for the target firms. The CAR 
Table 6.2 Descriptive statistics belonging to acquiring firms

\begin{tabular}{|c|c|c|c|c|c|c|c|c|c|}
\hline Day & Mean & Med. & St. Dev. & Kurt. & Skew. & Range & Min. & Max. & t-stat. \\
\hline-10 & -0.29 & -0.26 & 2.45 & -0.03 & 0.70 & 9.03 & -3.60 & 5.43 & -0.56 \\
\hline-9 & -0.25 & -0.13 & 1.55 & 0.18 & 0.13 & 6.24 & -3.54 & 2.71 & $-0.76\left(^{*}\right)$ \\
\hline-8 & 0.10 & 0.14 & 2.06 & 3.62 & 1.04 & 9.93 & -3.51 & 6.42 & 0.23 \\
\hline-7 & -0.14 & -0.42 & 2.00 & 1.14 & 0.21 & 9.17 & -4.77 & 4.40 & -0.32 \\
\hline-6 & 0.43 & 0.13 & 2.28 & -1.12 & 0.05 & 7.59 & -3.49 & 4.10 & $0.88\left(^{*}\right)$ \\
\hline-5 & 0.15 & 0.21 & 2.12 & 3.73 & 0.28 & 11.46 & -5.33 & 6.13 & 0.33 \\
\hline-4 & 0.88 & 0.26 & 2.90 & -0.12 & 0.74 & 10.63 & -3.10 & 7.53 & $1.42\left({ }^{\star \star}\right)$ \\
\hline-3 & -0.35 & -0.72 & 3.16 & 7.04 & 1.87 & 15.74 & -4.96 & 10.78 & -0.52 \\
\hline-2 & 0.41 & 0.66 & 1.60 & 1.61 & -1.07 & 6.91 & -3.98 & 2.93 & $1.19\left(^{*}\right)$ \\
\hline-1 & -0.32 & -0.81 & 3.80 & 3.18 & 1.28 & 17.96 & -7.78 & 10.18 & -0.39 \\
\hline 0 & 0.30 & 0.88 & 2.26 & 0.92 & -0.46 & 10.17 & -5.06 & 5.11 & 0.62 \\
\hline 1 & -0.53 & -0.08 & 2.31 & 0.09 & -0.05 & 9.62 & -5.05 & 4.57 & $-1.07\left(^{*}\right)$ \\
\hline 2 & -0.48 & -0.81 & 1.48 & -0.67 & 0.47 & 5.20 & -2.64 & 2.56 & $\left.-1.53{ }^{(* *}\right)$ \\
\hline 3 & -0.11 & -0.22 & 2.03 & 0.16 & 0.10 & 8.34 & -4.39 & 3.95 & -0.24 \\
\hline 4 & 0.24 & 0.08 & 1.19 & -0.90 & 0.42 & 4.17 & -1.55 & 2.62 & $0.95\left(^{*}\right)$ \\
\hline 5 & -0.76 & -1.36 & 2.10 & -0.14 & 0.80 & 7.42 & -3.71 & 3.71 & $\left.-1.69^{* * *}\right)$ \\
\hline 6 & -0.91 & -0.88 & 1.49 & -0.52 & 0.02 & 5.44 & -3.46 & 1.97 & $-2.88(* * * \star)$ \\
\hline 7 & 0.53 & -0.01 & 1.59 & 3.77 & 1.68 & 7.33 & -1.75 & 5.57 & $\left.1.57^{* \star \star}\right)$ \\
\hline 8 & 0.20 & -0.14 & 1.54 & -1.05 & 0.48 & 5.01 & -1.94 & 3.07 & 0.60 \\
\hline 9 & 0.11 & 0.47 & 1.65 & 1.51 & -0.43 & 7.58 & -3.62 & 3.96 & 0.31 \\
\hline 10 & -0.34 & -0.35 & 1.49 & 0.00 & 0.33 & 5.87 & -2.94 & 2.93 & $-1.07\left(^{* *}\right)$ \\
\hline
\end{tabular}

Source: www.analiz.com

increases until about the announcement day and then starts to decrease due to the abnormal returns being positive until the announcement day and then being negative, on the average. The investor is expected to get additional cumulative return of $7 \%$ should he be invested in the M\&As traded on the ISE.

The situation is similar for the bidder firms but the picture is a bit more mixed and the returns are somewhat smaller than the target firm returns. The same investor's additional cumulative return is less than $1 \%$ should he be invested in the acquiring firms. This CAR would not be maintained as positive if the investor kept on investing in the same firms following the announcement date and the loss would become more if the investor remained with the same securities.

We furthermore analyze whether there have been structural changes in the behaviors of the returns represented by the market model regression equation. We advance a version of the Chow test (1960) to conclude in the existence of a structural change. The null hypothesis this time claims that there is no structural change in the regression line, $H_{0}$ : No structural change, against the alternative of the structural change. More formally, what is meant by the structural change in the regression equation is that there is 


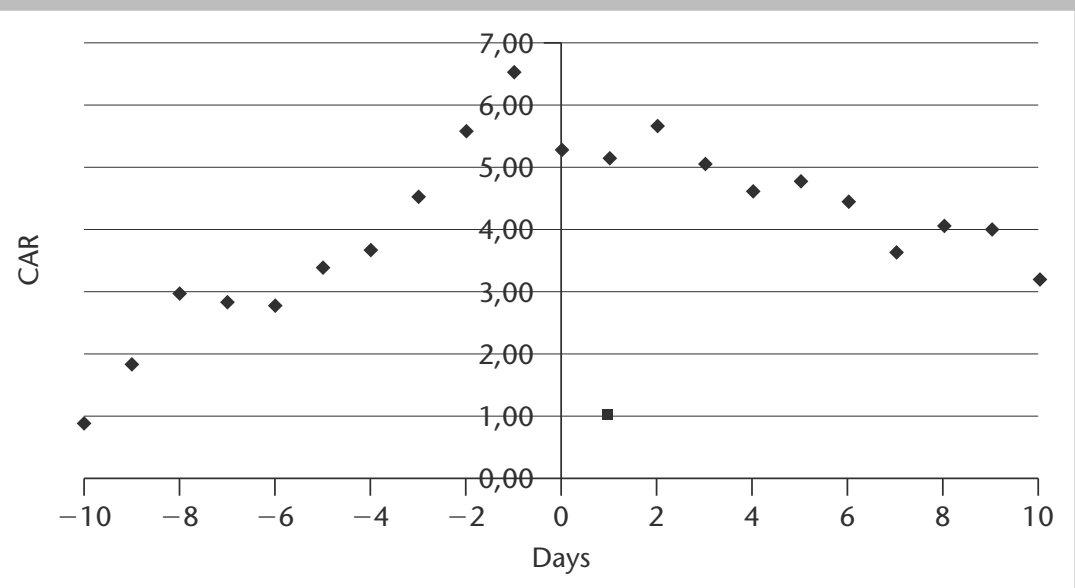

Figure 6.1 CAR for target firms

Source: www.analiz.com

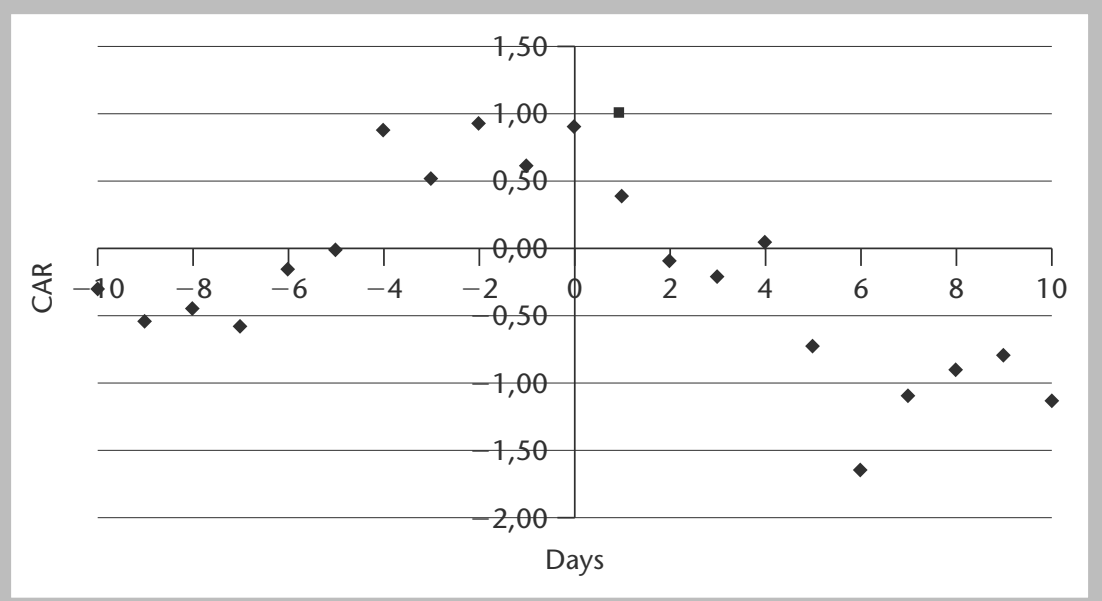

Figure 6.2 CAR for bidder firms

Source: www.analiz.com

change in at least one of the parameters in the regression equation of the market model. That is, either $\alpha$ or $\beta$ or both in Equation [1] for the firm must be significantly different in pre- and post- periods.

The whole period of 120 day observations are separated to the pre-and post-periods with the pivot day of the announcement time. There are 90 observations in the pre-period $\left(n_{1}=90\right)$ and 30 observations in the postperiod $\left(n_{2}=30\right)$ adding up to a total of 120 observations $(n=120)$. The residual sum of squares are calculated for all these three periods and called 
Table 6.3 F-statistics for testing the structural change, acquiring firms

\begin{tabular}{rlll}
\hline Firm & F-stat. & Firm & F-stat. \\
\hline 1 & $\left.2.11^{*}\right)$ & 12 & $3.19\left(^{* * *}\right)$ \\
2 & $2.7\left(^{* *}\right)$ & 13 & 0.66 \\
3 & $2.29\left(^{*}\right)$ & 14 & 1.30 \\
4 & 1.29 & 15 & $1.58\left(^{*}\right)$ \\
5 & 1.18 & 16 & $2.92\left(^{* *}\right)$ \\
6 & 0.24 & 17 & 1.30 \\
7 & 0.22 & 18 & 0.08 \\
8 & $3.18\left(^{* * *}\right)$ & 19 & $2.43\left(^{* *}\right)$ \\
9 & 0.39 & 20 & 1.06 \\
10 & $3.23\left(^{* *}\right)$ & 21 & 0.16 \\
11 & $2.65\left(^{* *}\right)$ & 22 & 0.32 \\
\hline
\end{tabular}

Source: www.analiz.com

$\mathrm{RSS}_{\text {pre, }} \mathrm{RSS}_{\text {post, }}$ and $\mathrm{RSS}_{\text {whole, }}$ respectively after the calculation of the OLS parameter estimates for these three periods one by one.

The test statistic: $F=\frac{\left(R S S_{\text {whole }}-R S S_{\text {pre }}-R S S_{\text {post }}\right) / k}{\left(R S S_{\text {pre }}+R S S_{\text {post }}\right) /\left(n_{1}+n_{2}-2 k\right)}$ follows the F-distribution with $(k)$ numerator degrees of freedom and $\left(n_{1}+n_{2}-2 k\right)$ denominator degrees of freedom.This statistic is calculated for all bidder firms and listed in Table 6.3. The F-critical values for $1 \%, 5 \%, 10 \%$, and $25 \%$ significant levels for $(2,116)$ numerator and denominator degrees of freedom are 4.80 , $3.08,2.35$, and 1.40 respectively. All test statistics are evaluated according to these critical values and the rejections based on these significance levels are indicated by $\left(^{*}\right),\left({ }^{* *}\right),\left({ }^{* *}\right)$, and $\left(^{* * *}\right)$ for $25 \%, 10 \%, 5 \%$, and $1 \%$ significance levels. Test results conclude that 10 out of 22 acquiring firms experience the structural change.

Table 6.4 reports the test results for the target firms. These test results reveal that about two thirds of the target firms have experienced structural changes around the announcement date with about one third being highly significant. The structural changes are observed more for the target firms than the acquiring firms. 23 out of 30 target firms experience the structural changes. The significance levels are larger for the target firms as well.

Average abnormal returns between days -10 and +10 around announcement date are provided in Table 6.5 for several firm- and M\&A-specific factors. It appears that AAR is larger for cross-border than domestic M\&As. Particularly for target firms, we notice a large and positive average abnormal return. On the other hand, for acquirer firms, AAR indicates a larger decline in firm value for cross-border than domestic activity. Similar result can be 
Table 6.4 F-statistics for testing the structural change, target firms

\begin{tabular}{|c|c|c|c|}
\hline Firm & F-stat. & Firm & F-stat. \\
\hline 1 & 0.82 & 16 & $1.45\left(^{*}\right)$ \\
\hline 2 & $7.30\left(^{*}\right)$ & 17 & $2.09\left(^{*}\right)$ \\
\hline 3 & $2.53\left({ }^{* *}\right)$ & 18 & $2.94(* *)$ \\
\hline 4 & 0.82 & 19 & $1.77\left(^{*}\right)$ \\
\hline 5 & $1.61\left(^{*}\right)$ & 20 & 0.73 \\
\hline 6 & $7.91(* * * *)$ & 21 & $4.71(* \star *)$ \\
\hline 7 & $11.20\left(^{* * * *}\right)$ & 22 & $\left.2.611^{* *}\right)$ \\
\hline 8 & $5.05(* * * *)$ & 23 & $4.38\left({ }^{* \star *}\right)$ \\
\hline 9 & 0.78 & 24 & $\left.3.56^{* * *}\right)$ \\
\hline 10 & 1.15 & 25 & $1.73\left(^{*}\right)$ \\
\hline 11 & $\left.4.48{ }^{* * * *}\right)$ & 26 & $2.27\left(^{* \star}\right)$ \\
\hline 12 & 0.30 & 27 & $3.23(* * *)$ \\
\hline 13 & $3.26\left(^{* * *}\right)$ & 28 & $4.11\left(^{* * *}\right)$ \\
\hline 14 & $1.55\left(^{\star}\right)$ & 29 & $3.63(* * *)$ \\
\hline 15 & 0.97 & 30 & $4.84\left(^{*}\right)$ \\
\hline
\end{tabular}

Source: www.analiz.com

Table 6.5 Firm and M\&A Specific Factors and AAR

\begin{tabular}{|c|c|c|c|c|c|c|}
\hline & \multirow[b]{2}{*}{ No } & \multirow[b]{2}{*}{ Yes } & \multicolumn{2}{|c|}{ Acquirer Firm } & \multicolumn{2}{|c|}{ Target Firm } \\
\hline & & & No & Yes & No & Yes \\
\hline Cross-border M\&A & $1.7 \%$ & $13.3 \%$ & $-1.3 \%$ & $-30.9 \%$ & $6.9 \%$ & $20.2 \%$ \\
\hline Same-industry M\&A & $-1.5 \%$ & $12.5 \%$ & $-14.3 \%$ & $0.8 \%$ & $7.3 \%$ & $21.5 \%$ \\
\hline Foreign Partners ${ }^{(a)}$ & $12.4 \%$ & $-11.2 \%$ & $-3.4 \%$ & $-24.1 \%$ & $26.7 \%$ & $-7.3 \%$ \\
\hline Family Ownership ${ }^{(b)}$ & $-15.5 \%$ & $21.5 \%$ & $-40.0 \%$ & $4.8 \%$ & $-7.8 \%$ & $41.8 \%$ \\
\hline International Activity(c) & $-1.0 \%$ & $16.1 \%$ & $-25.8 \%$ & $19.2 \%$ & $24.1 \%$ & $10.9 \%$ \\
\hline Larger firm $^{(d)}$ & $2.0 \%$ & $11.2 \%$ & $8.5 \%$ & $-25.4 \%$ & $-4.5 \%$ & $30.5 \%$ \\
\hline
\end{tabular}

(a) Foreign Partners indicates existence of pre-M\&A partnership with foreign firms or investors.

(b) Family Ownership indicates that acquirer or target firms have at least one family/individual as a major shareholder.

(c) International Activity shows that firms have positive levels of exports or imports.

(d) Larger Firm shows the size of the firm through number of employees. Firms with employees more than the median level (1833) are assumed to be large. Average number was 6519 for large firms, while it was 470 for others.

Sources: Istanbul Stock Exchange (www.imkb.gov.tr), www.analiz.com, Bloomberg. 
seen for the same-industry transactions, with $21.5 \%$ increase in the stock return above the expected level for target firms if acquirer and target firms are in the same industry.

Existence of foreign partnership before the announcement date, surprisingly, indicates a lower post-M\&A abnormal return ${ }^{14}$. Contrary to our expectations, family ownership leads to a higher post-merger return. As discussed in the literature, family ownership and control is expected to be positively associated with better performance and higher firm value (e.g., Maury, 2006; Maury and Pajuste, 2005; Barth et al., 2005; Davies et al., 2005). Accordingly, investors should expect moderate gains in performance and firm value post-M\&A since these firms are expected to operate close to their efficiency frontier. We also notice that both the level of international activity, measured either by the non-negative levels of exports or imports, and the size of the firm, measured by the pre-merger number of employees, lead to a larger increase in post-M\&A returns. In general, consistent with the earlier findings, Table 6.5 shows that target firms exhibit larger increase in firm value around the announcement date as measured by cumulative average abnormal returns.

The relationship between firm- and merger-specific factors and likelihood of observing positive abnormal return is analyzed by estimating the following equation.

$$
\mathrm{P}(\mathrm{AAR})_{\mathrm{i}}=\mu+\mathrm{X}_{\mathrm{i}} \beta+\varepsilon_{\mathrm{i}}
$$

In this equation, $P(A A R)_{i}$ is a binary variable taking a value of one for firm $i$ when average abnormal return of this firm is greater than zero. Otherwise, it takes a value of zero. The matrix $\boldsymbol{X}_{i}$ includes a measure of firm size, an indicator variable for cross-country mergers and acquisitions, an indicator for target firms, indicators for ownership structures (namely for the existence of major foreign and family shareholders), an indicator for the same industry transactions, and finally an indicator for the existence of international transactions ${ }^{15}$. As a link function, we use logistic distribution ${ }^{16}$. With this analysis, our objective is to identify the factors that significantly impact the likelihood of positive average abnormal returns at the M\&A level ${ }^{17}$. Results are presented in Table 6.6.

Based on \% concordant and c-value, we can decide that model fit is acceptable. Signs of the coefficients are consistent with Table 6.5 presentations. However, out of seven variables, only three of them are statistically significant. Not surprisingly, Table 6.6 shows that being a target rather than acquirer increases the probability of realizing a positive abnormal return around the announcement date. Moreover, existence of international transactions also positively impacts the likelihood of positive abnormal returns. As discussed earlier, family ownership seems to have a positive impact on this probability as well. 
Table 6.6 Firm and M\&A specific factors and likelihood of observing abnormal returns

\begin{tabular}{lcccccc}
\hline Cross-border & $\begin{array}{c}\text { Same } \\
\text { Industry }\end{array}$ & Foreign & Family & $\begin{array}{c}\text { International } \\
\text { Activity }\end{array}$ & Size & Target \\
\hline 0.0925 & 0.4850 & -1.1719 & $1.4196^{*}$ & $1.2144^{*}$ & 0.0585 & $1.4532^{*}$ \\
$(.8457)$ & $(.7192)$ & $(.8483)$ & $(.7474)$ & $(.7226)$ & $(.165)$ & $(.874)$ \\
\% concordant: 77.2 & & & & & \\
c-value: 0.775 & & & & & & \\
\hline
\end{tabular}

Standard errors are provided in parantheses.

$* * *, * *$, and * represent significance at $1 \%, 5 \%$ and $10 \%$ levels, respectively.

Size is measured by the log of number of employees. All the other variables are binary variables with a value of one representing the variable definition.

Sources: Istanbul Stock Exchange (www.imkb.gov.tr), www.analiz.com, Bloomberg.

\subsection{CONCLUSION}

This study examines the short-term impacts of merger and acquisitions on firm value for Turkish acquirer and target firms through an event-study approach. Given the recent increase in the number and value of M\&A activity in Turkey, it becomes more important to understand the size and direction of change in firm value. Consistent with the existing literature, we find that target firms realize larger increases in firm value than acquirer firms. The observed increase in the CAAR before the announcement date indicates the existence of information spillover. An application of Chow test reveals that target firm returns have more structural changes than acquirer firm returns. Furthermore, the null of "no structural change" is more significantly rejected for target firms.

By investigating firm-specific and M\&A-specific factors separately, we also find that larger firms, firms with a major family shareholder, and firms with international transactions realize a larger positive abnormal return. In addition, cross-border and same-industry M\&A activity leads to a larger positive abnormal return. Pre-M\&A existence of foreign major shareholders, on the other hand, causes a decrease in firm value post-M\&A. An examination of the relationship between these factors and the likelihood of observing an increase in firm value show that only family ownership, existence of international transactions and being a target firm significantly impacts the probability.

Given the increasing number of mergers and acquisitions in Turkey, there is room for further research to investigate the relationship between macroeconomic factors and M\&As. In addition, more recent announcements of bank mergers in Turkey provide an opportunity to investigate efficiency gains in the future. 


\section{NOTES}

1. Industry shocks can be economic, regulatory or technological. Harford (2005) shows that industry shocks are the main drivers for merger waves but sufficient capital liquidity is required.

2. Some sources of firm value can be more important at certain times and be correlated with the reasons for the merger wave to start (Andrade et al., 2001).

3. Such as size of the firm, growth of the firm,etc.

4. Epstein (2005) examines the factors for mergers to be succesful and discusses six determinants: strategic vision and fit, deal structure, due diligence, premerger planning, post-merger integration, and external factors. This study also indicates that merger of equals will be more likely to cause power struggles within the merged company to be unsuccesful in terms of wealth gains.

5. Peristiani (1997) finds that mergers do not create value for banking sector when X-efficiency is used as the measure. However, there does seem to be a moderate improvement when scale efficiency is used, which is mostly caused by the lower scale-efficiency of the target firms.

6. Coodth et al. (2006), using a panel data set, find that size of the knowledge base improves the post-M\&A performance in the mid-run.

7. Most studies concentrate on the banking or financial services. For example, Amihud et al. (2002) investigate the effect of mergers on risk for banking sector. They find that the risk of the acquiring bank do not change after the merger.

8. Differences in laws, regulations, language and geographical distance will increase the information and monitoring costs (Amihud et al., 2002; Buck and DeLong, 2004).

9. In fact, we observe an increasing M\&A activity before 2001 crisis in Turkey with some decline during the crisis. Since 2002, the level of activity shows an increasing trend. The number of M\&A activity between 1997 and 2005 are: 5, 52, 76, 101, 82, 54, 80, 91, and 164 (Aydın, 2004; Ada et al., (2006), Ernst \& Young 2005 M\&A report).

10. Based on the announced transaction values.

11. As shown by Kıymaz (2004), macrovariables also play significant roles in explaining wealth gains. Given that our sample mostly includes announcements in 2004 and 2005 , we were not able to incorporate this line of research into our analysis.

12. Given that currently there are 261 firms traded on the ISE, this should not be too surprising.

13. Index includes 100 firms traded in the Istanbul Stock Exchange.

14. Foreign partnership is defined as the existence of major foreign shareholder in the previous accounting year of the announcement year.

15. Variable descriptions are provided under table 6.5 and table 6.6.

16. Instead of using logistic regression which uses logistic distribution as the link function, one can also use probit regression which uses normal distribution as the link function for estimation. In most cases, as in this one, results should not be different from each other. For details on logistic/probit regression, see Greene (1997, chapter 19).

17. Given that the size differences in abnormal returns might not be different from each other significantly, through this approach, we are hoping to see which factors causes positive abnormal returns.

\section{REFERENCES}

Ada, E., Demirhan, D. and Gökalp, F. (2006) “Şirket, birleşme ve satınalmalarının stratejik önemi ve işletmelerin piyasa değeri üerine etkisi", Analiz, 6(15): 29-38. 
Amihud, Y., DeLong, G.L. and Saunders, A. (2002) "The Effects of Cross-border Bank Mergers on Bank Risk and Value", Journal of International Money and Finance, 21: 857-77. Andrade, G., Mitchell, M. and Stafford, E. (2001) "New Evidence and Perspectives on Mergers", Journal of Economic Perspectives, 15(2): 103-20.

Aydın, N. (2004) "Birleşme ve satınalmalarda işletme değrlemesi", in Şirket Birleşmeleri, (ed.), by H. Sumer and H. Pernsteiner, 193-211.

Barth, E., Gulbrandsen, T. and Schone, P. (2005) "Family Ownership and Productivity: The Role of Owner-management", Journal of Corporate Finance, 11: 107-27.

Bessler, W. and Murtagh, J.P. (2002) "The Stock Market Reaction to Cross-border Acquisitions of Financial Services Firms: An Analysis of Canadian Banks", Journal of International Financial Markets, Institutions and Money, 12: 419-40.

Buck, C.M. and DeLong, G. (2004) "Cross-border Bank Mergers: What Lures the Rare Animal?", Journal of Banking \& Finance, 28: 2077-102.

Cheng, L.T.W. and Leung, T.Y. (2004) "A Comparative Analysis of the Market-based and Accounting-based Performance of Diversifying and Non-diversifying Acquisitions in Hong Kong", International Business Review, 13: 763-89.

Chow, G.C. (1960). "Tests of Equality between Sets of Coefficients in Two Linear Regressions", Econometrica, 28(3): 591-605.

Cloodt, M., Hagedoorn, J. and Van Kranenburg, H. (2006) "Mergers and Acquisitions: Their Effect on the Innovative Performance of Companies in High-tech Industries", Research Policy, 35: 642-54.

Davies, J.R., Hillier, D. and McColgan P. (2005) “Ownership Structure, Managerial Behavior and Corporate Value", Journal of Corporate Finance, 11: 645-60.

DeLong, G.L. (2001) "Stockholder Gains from Focusing Versus Diversifying Bank Mergers", Journal of Financial Economics, 59: 221-52.

Epstein, M.J. (2005) "The Determinants and Evaluation of Merger Success", Business Horizons, 48: 37-46.

Greene, W.H. (1997) Econometric Analysis, 3rd edition, Englewood Cliff, NJ: Prentice-Hall.

Gugler, K., Mueller, D.C., Yurtoglu, B.B. and Zulehner, C. (2003) “The Effects of Mergers: An International Comparison", International Journal of Industrial Organization, 21: $625-53$.

Harford, J. (2005) “What Drives Merger Waves?", Journal of Financial Economics, 77: 529-60.

Kıymaz, H. (2004) "Cross-border Acquisitions of US Financial Institutions: Impact of macroeconomic factors", Journal of Banking \& Finance, 28: 1413-39.

Kıymaz, H. and Mukherjee, T.K. (2001) "Parameter Shifts when Measuring Wealth Effects in Cross-border Mergers", Global Finance Journal, 12: 249-66.

Maury, B. (2006). "Family Ownership and Firm Performance: Empirical Evidence from Western European Corporations," Journal of Corporate Finance, 12: 321-41.

Maury, B. and Pajuste, A. (2005) "Multiple Large Shareholders and Firm Value", Journal of Banking \& Finance, 29: 1813-34.

Peristiani, S. (1997). "Do Mergers Improve the X-efficiency and Scale Efficiency of US Banks? Evidence from the 1980s", Journal of Money, Credit and Banking, 29(3) 326-37.

Rossi, S. and Volpin, P.F. (2004) "Cross-country Determinants of Mergers and Acquisitions", Journal of Financial Economics, 74: 277-304.

Scholtens, B., de Wit, R., (2004) "Announcement Effects of Bank Mergers in Europe and the US", Research in International Business and Finance, 18: 217-28. 